\title{
Ritual vs. retaliatory killing of African lions in the Ngorongoro Conservation Area, Tanzania
}

\author{
Dennis Ikanda ${ }^{1}$, Craig Packer ${ }^{2, *}$ \\ ${ }^{1}$ Tanzania Wildlife Research Institute, Box 661, Arusha, Tanzania \\ ${ }^{2}$ Department of Ecology, Evolution \& Behavior, University of Minnesota, 1987 Upper Buford Circle, St. Paul, \\ Minnesota 55108, USA
}

\begin{abstract}
The Ngorongoro Conservation Area (NCA), Tanzania, is a multiple land-use area where Maasai pastoralists co-exist with large migratory herbivores and associated carnivores. Maasai retaliate against lions, leopards and hyenas that prey upon their livestock. Cattle depredation is mostly by lions and most common in grazing herds tended solely by children (rather than by warriors) and in large herds tended by few herders. Depredation on sheep and goats (shoats) is mostly by leopards and is more difficult to prevent. Across all carnivore species, nocturnal depredation is somewhat more common in smaller households. Over most of the NCA, lion killing is proportional to the amount of cattle depredation by resident lions, but nomadic lions from the Serengeti National Park appear to be killed more exclusively for cultural purposes (Ala-mayo) in the open plains. While the impact of ritual hunting on the Serengeti lion population as a whole appears to be trivial, retaliatory killing on resident lions in the NCA may intensify as the human population continues to increase.
\end{abstract}

KEY WORDS: Carnivores · Livestock husbandry · Livestock depredation · Ala-mayo · Tanzania Resale or republication not permitted without written consent of the publisher

\section{INTRODUCTION}

The Maasai rangelands of East Africa are home to several of the largest remaining lion populations on the continent. Many parts of Maasai land have been preserved as National Parks (e.g. Serengeti, Tarangire, Amboseli, and Nairobi Parks) and Game Reserves (e.g. Mkomazi and Loliondo), but none of these protected areas are fenced and lions frequently kill Maasai cattle in adjacent rangelands (Kolowski \& Holekamp 2006, Kissui 2008). Although Maasai pastoralists have traditionally co-existed with wildlife, their cattle holdings have remained relatively constant over the past few decades despite rapid human population growth, resulting in fewer livestock per capita and hence a lower tolerance for depredation, as family wealth is measured by the number of livestock (Homewood \& Rodgers 1991, Coast 2002, McCabe 2003). In addition, adherence to traditional cultural beliefs still motivates lion hunting by Maasai youth even though ritual lion hunting (Ala-mayo) was banned in the 1970s (Thompson 1997); secrecy surrounding these rituals generally makes it impossible for wildlife managers to enforce the ban (Spencer 1988).

Tanzania's 8292 km² Ngorongoro Conservation Area (NCA) was established in 1959 as the world's first multiple land-use conservation area, where Maasai pastoralists could reside within a fully protected wildlife area, provided they maintained their traditional way of life (Fosbrooke 1972). Unlike their counterparts in southern Kenya or in other parts of Tanzania, most of the NCA Maasai have retained a purely pastoralist lifestyle, living in temporary shelters and migrating according to the needs of their livestock (Thompson 1997).

The NCA was set aside as a multiple land-use area because of the extraordinary cultural value of the Ngorongoro Crater Highlands to the Maasai, but the NCA also contains the eastern third of the Greater Serengeti Ecosystem, specifically the volcanic grasslands where the migratory Serengeti wildebeest calve each February (Sinclair \& Norton-Griffiths 1979). Although these short-grass plains hold very few resident lions, nomadic lions follow the migratory herds 
into the NCA each wet season. The NCA also contains the $250 \mathrm{~km}^{2}$ Ngorongoro Crater, which provides a largely self-contained ecosystem, but various wildlife species (including a small proportion of the lion population) leave the Crater floor each wet season. Thus the Maasai have legislatively protected rights to live in the NCA in perpetuity but consequently face continuous exposure to large numbers of wild lions.

Cohorts of Maasai youth (14 to 24 yr of age) are initiated into the warrior (Morani) class by a circumcision ceremony and a 2 mo sojourn, during which they must survive away from their families and find their own food and water (Spear \& Waller 1993, Coast 2002). Upon their return, the Moranis carry spears and defend their clans against bandits, cattle thieves, and livestock predators; the Moranis become elders when the next cohort reaches maturity (usually after about 10 yr). By killing a lion, a Morani demonstrates his courage and strength (Spear \& Waller 1993). The Alamayo may be a purely cultural act or in retaliation against a livestock attack. In either case, the hunt is organized in advance and the participating Moranis compete against each other to be the first to spear the lion. Successful warriors are given a hero's welcome and celebrated by the entire community, thus retaliatory killings elicit the same honor and social respect as ritual lion killings. We document the approximate size and distribution of the resident lion population in the pastoralist areas of the NCA, describe Maasai husbandry practices, evaluate their responses to livestock depredation and show that cultural practices remain an important motivation for lion-killing in at least one part of the short-grass plains of the NCA.

\section{MATERIALS AND METHODS}

Study area. The NCA is located in northern Tanzania between 34 to $36^{\circ} \mathrm{E}$ and $2^{\circ} 30^{\prime}$ to $3^{\circ} 37^{\prime} \mathrm{S}$ (Fig. 1). Habitat ranges from cool, wet montane forest high-

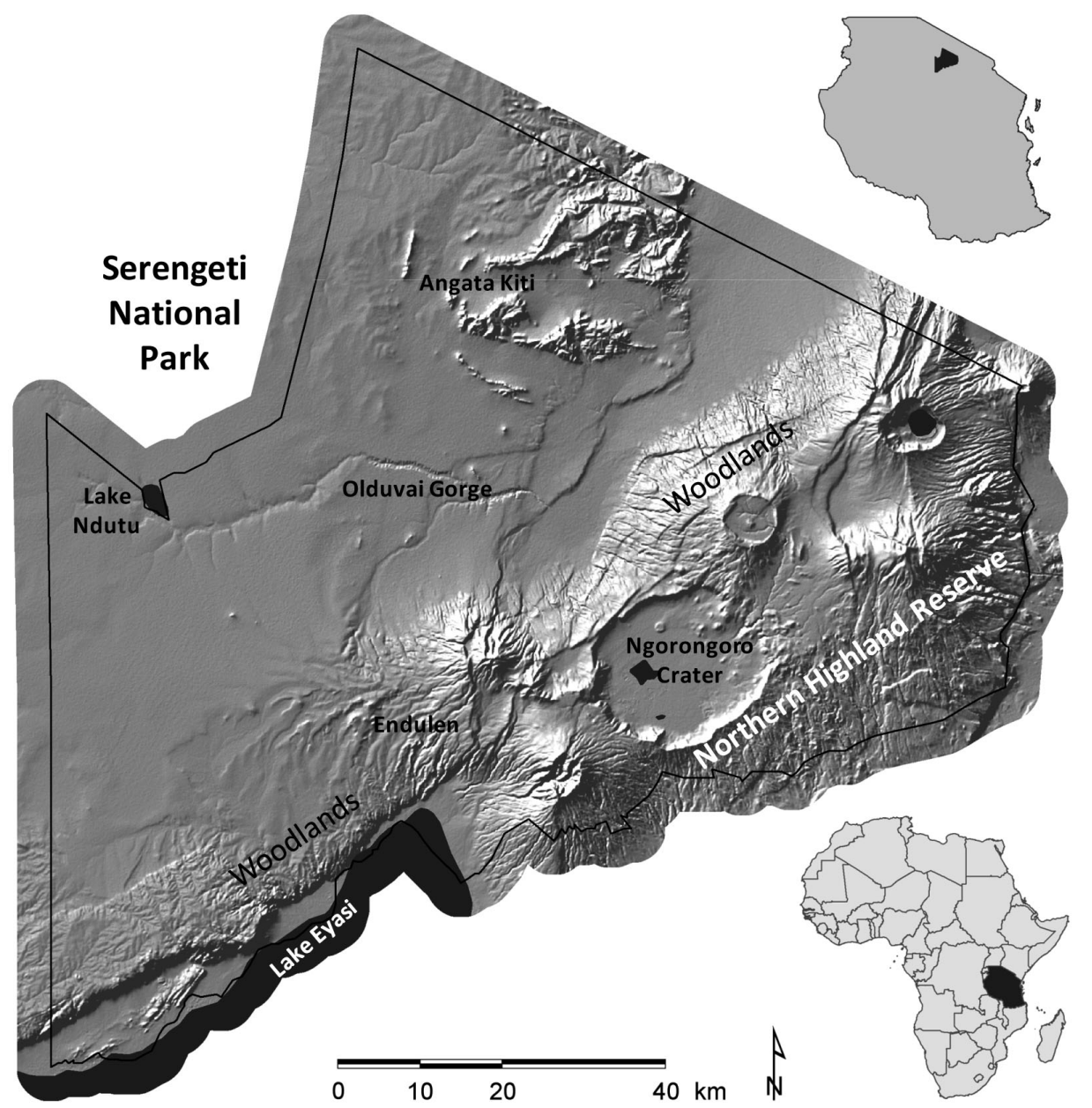

Fig. 1. Ngorongoro Conservation Area (taken from Farr et al. 2007), Tanzania. The study was conducted in all parts of the Conservation Area except for the Northern Highland Reserve and the floor of Ngorongoro Crater. Areas of light topographic relief are dominated by short-grass plains 
lands in the east (Fig. 1) to extensive short grass plains in the west, separated by a transition zone of Acacia and Commiphora woodlands. The Ngorongoro Crater has been designated as a core wildlife reserve since 1974, whereas the Ngorongoro Maasai can utilize the rest of the NCA for pastoralism. Lions and other large carnivores may be legally killed in defense of human life and livestock in the pastoralist areas of the NCA, which the Maasai have occupied for more than $200 \mathrm{yr}$ (Homewood \& Rodgers 1987).

Lion spatial patterns. We estimated the distribution and abundance of lions in the pastoralist NCA through a total of 36 field surveys between January 2001 and January 2004. Pastoralist areas of the NCA were surveyed approximately once per month using a $4 \mathrm{WD}$ vehicle and the assistance of the Maasai. The Maasai informants provided details of recent lion sightings and expertise on how best to access these locations. Lions were tracked by driving transects through the area. Lion spoor, vocalizations and the behavior of scavenging hyenas and vultures also provided cues for locating lions. Other records were available on the ranging patterns of all individually recognized lions monitored in the Serengeti National Park (Fig. 2). Participatory Rural Appraisals (PRA) were also conducted monthly using questionnaire-guided interviews with the Maasai at 43 different bomas, and remotely stationed management authorities at 7 ranger posts and several other remote stations (Borrini-Feyerabend \& Buchan 1997). A boma is a typical Maasai homestead, consisting of several cattle and shoat kraals encircled by a series of huts belonging to an elder and his wives.
Shoat refers to sheep and goat combined as small stock. All villagers were able to identify lions by using the correct name in Ki-Maa, contributing a total of 60 lion sightings by Maasai (12.3\% of 489 interviews) and 17 sightings by NCA management staff $(29.8 \%$ of 57 interviews) between January 2001 and August 2003.

Maasai husbandry techniques. We employed PRA techniques, including semi-structured interviews, focal group interviews, questionnaires and village walks (Borrini-Feyerabend \& Buchan 1997) to measure the strategies employed by Maasai to protect their cattle against livestock attacks. A total of 43 bomas (representing $2.8 \%$ of the $\sim 1600$ bomas in the NCA) were monitored for 4 to 24 mo between September 2001 and August 2003, depending upon the mobility status (seasonally vs. permanently occupied) of the boma and the level of cooperation offered by respondents. Bomas were chosen across the entire pastoral area based upon their proximity to relevant lion-habitat features such as waterholes, topographic and vegetative cover, as well as accessibility by vehicle. Each boma was classified by direct observation according to type (thorn brush or wooden poles), fencing characteristics (single or doubled walled, wall height, width, and transparency), deterrent factors (number of people, presence of dogs), habitat (woodland, plains, mountainous, near river, etc.), and distance to neighboring bomas (Ogada et al. 2003). The total livestock holdings for the 43 bomas were 12819 animals, comprising 5018 $(39.1 \%)$ cattle, $7103(55.4 \%)$ sheep/goats or shoats, and $696(5.4 \%)$ donkeys. We collected independent samples of herding characteristics by direct observa-
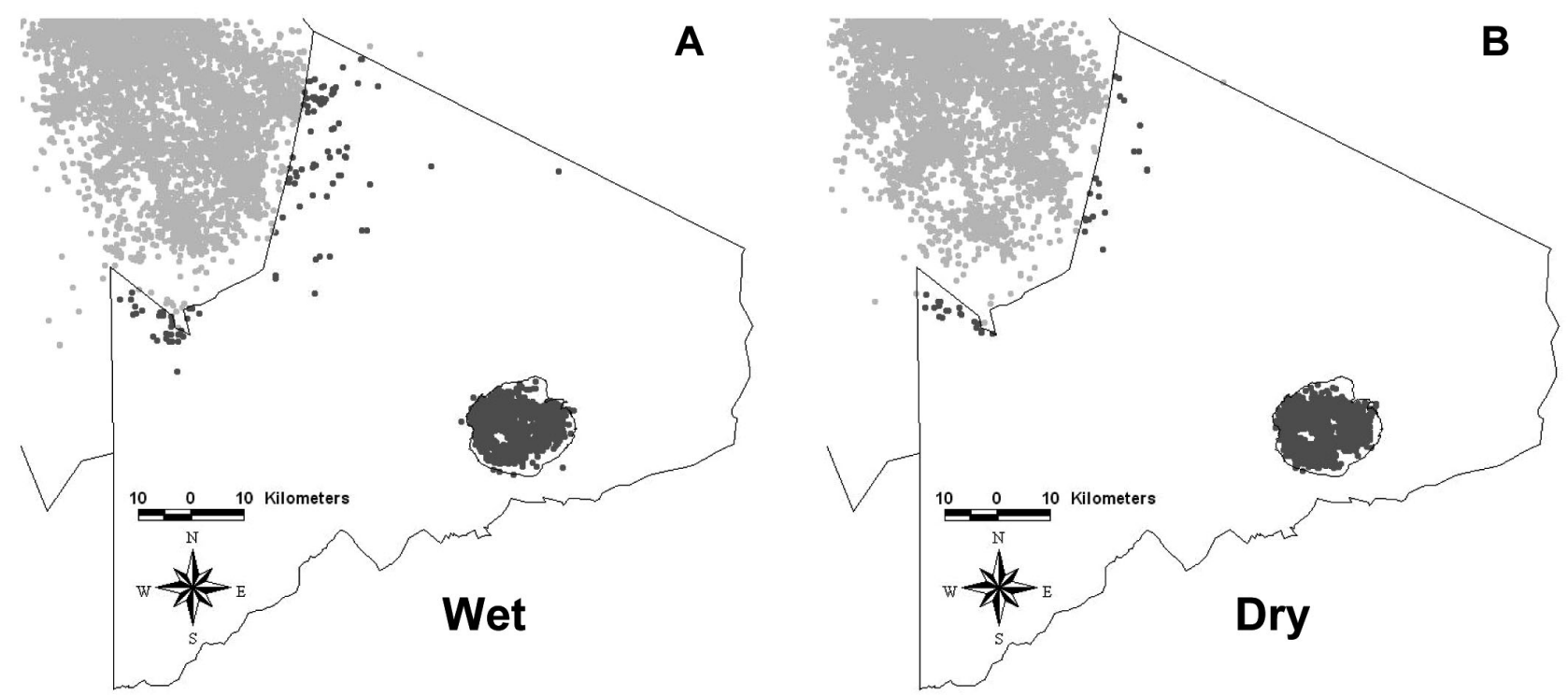

Fig. 2. Panthera leo. Lion sightings by the Serengeti lion project 1984-2004 inside the Serengeti National Park (light grey) and in the Ngorongoro Conservation Area (dark grey), as well as sightings of the Ngorongoro Crater lions (also in dark grey; all of which were in or near the Crater) during (A) wet and (B) dry seasons 
tions of 144 herds in the field. Surveys were performed at the end of the wet season when livestock were concentrated in the lowland open areas and herds could be easily approached and assessed. The following variables were recorded: type and size of herd, age, number and behavior of herders, and habitat classification (plains, woodlands, waterhole, river gorge, etc.).

Maasai-inflicted lion mortality. Since Ala-mayo is illegal, the Maasai were initially reluctant to admit killing lions for fear of arrest by conservation officers. But after gradually gaining their trust through repeated visitations and open dialogue, we conducted focus-group interviews at Olduvai in June 2003 and at Endulen in July 2003 with groups of Maasai male elders to gain relevant information. We chose the elders due to their extensive knowledge and their status as key spokesmen for the Maasai community. Olduvai and Endulen reported high rates of humanlion interaction and respondents were asked to name all people injured or killed by lions, the context of the attacks and the fate of all lions encountered in retaliatory activity. This method revealed 81 lion-Maasai encounters leading to a minimum of 69 lion mortalities between 1965 and 2003. Due to the difficulty in ascertaining the exact motives surrounding each case (see 'Discussion'), we obtained a Maasai calendar detailing the initiation dates for young men entering into the Morani class, when Ala-mayo was expected to be most common. These dates were plotted against the number of lions killed each year (see Fig. 5) to indicate the possible influence of Ala-mayo on lion mortality.

Statistical analyses. Linear regression analysis was performed in SPSS; non-parametric statistics were used if data were not normally distributed. All p-values are 2-tailed.

\section{RESULTS}

\section{Lion abundance and distribution}

Population estimates of resident lions in the $\sim 7900 \mathrm{~km}^{2}$ pastoralist NCA totalled a minimum of 27 individuals, split into at least 4 different prides with a continuous presence in Olduvai Gorge, Lake Ndutu, and Endulen. Maasai informants with a direct experience of livestock predation consistently described the distribution and seasonal movements of these 4 resident prides, as well as a seasonal pattern of lion abundance each wet season (December to May) on the short-grass plains, when the migratory Serengeti herds occupied the area. The Maasai recognized that these transient lions originated from the Serengeti National Park (SNP), as confirmed by longterm records from the Serengeti lion project (Fig. 2).
Similarly, Maasai living in the highlands adjacent to the Ngorongoro Crater occasionally sighted lions during the wet season but not during the dry season. Nearly all of the highlands informants suggested that these lions had followed wildebeest and zebra out of the crater.

\section{Livestock husbandry}

Between September 2001 and August 2003, 83\% of the sampled homesteads experienced livestock depredation either at the grazing pastures or within the kraals at the boma in a total of 89 carnivore attacks, with losses totaling at least 129 livestock (5.38 animals per month). Most (76.4\%) of these attacks occurred during the day when livestock were grazing away from the boma, compared to $23.6 \%$ of nighttime attacks at the boma. Across livestock species, $23.2 \%$ of the attacks were on cattle, $67.4 \%$ shoats, and $9.3 \%$ donkeys. This is equivalent to an annual offtake of $0.3 \%$ of the total cattle, $0.6 \%$ of the shoats, and $0.9 \%$ of the donkeys.

Maasai graze their livestock in open pastures by day where 1 to 3 herdsmen drive and protect the herd against carnivores by vigilance, loud noises, and sticks. The Moranis may also kill or repel predators with spears and shields. Lions were the primary predator of grazing cattle (68\% of attack events) followed by hyenas and leopards (16\% each), whereas leopards were the most common predator of grazing shoats $(79 \%)$, followed by lions $(13 \%)$, and hyenas $(5 \%)$. More than one-third of cattle herds (34\% of 334) were tended solely by children.

We measured monthly attack rates across all 43 homesteads and found no significant trends in the data, largely because so few herds had been attacked (only 8 attacked homesteads where the age of the cattle herders varied on different days; only 11 homesteads where cattle were attacked). However, a homestead may have avoided attack either because of more effective defenses against predation or because of an absence of carnivores in the immediate vicinity. Restricting the analysis to only those herds that were attacked at least once during the study, predation risks were significantly higher in grazing herds of cattle that were attended solely by children than in those attended solely by Moranis (Fig. 3A) and the risk of predation on herds of grazing cattle increased with the number of animals tended per herdsmen (Fig. 3B). However, the risk of predation on grazing shoats was not significantly affected by the herders' age-class or by the number of shoats per herdsman.

Predators attacked $37 \%$ of the bomas, with some bomas experiencing as many as one nighttime attack 


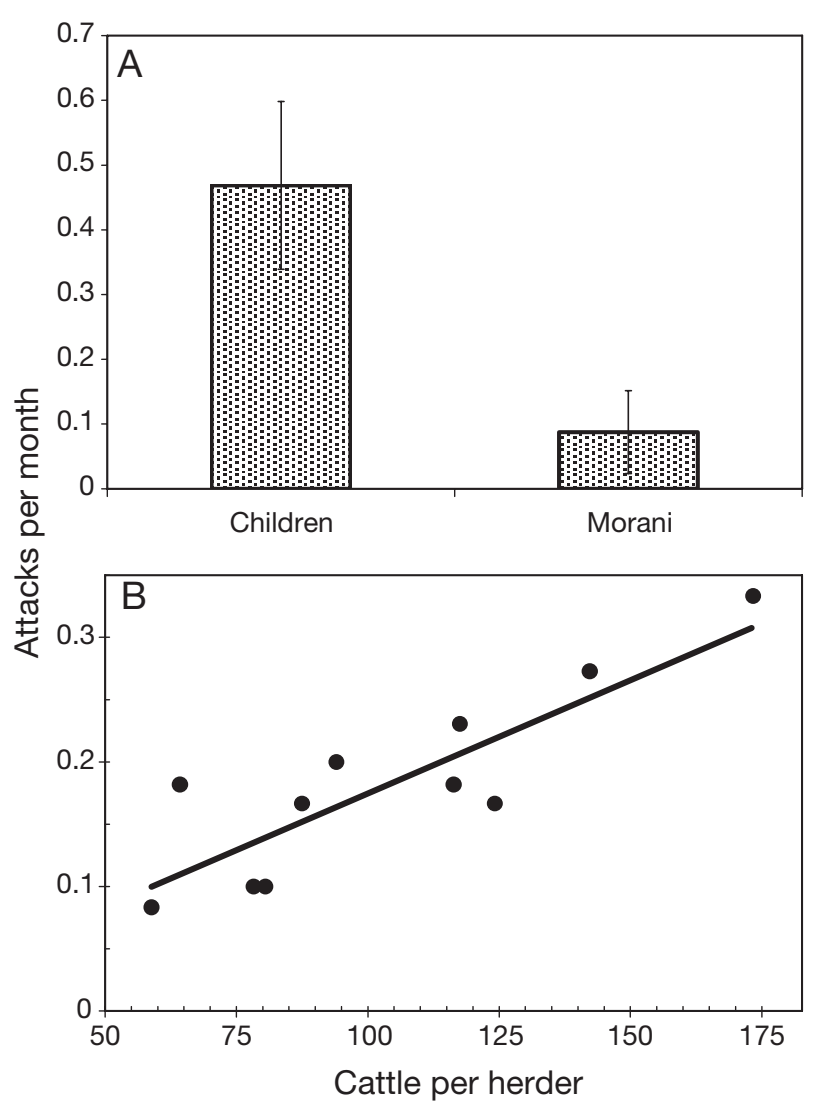

Fig. 3. Monthly risk of depredation on grazing herds of cattle. (A) Herds tended solely by children suffered higher rates of depredation than herds tended solely by Moranis $(\mathrm{T}=6, \mathrm{n}=8$ homesteads suffering at least one attack during the study, $\mathrm{p}=$ 0.05, Wilcoxon matched-pairs test); vertical bars indicate standard errors. (B) Risk of attack increased with the average number of cattle tended by each herdsman $\left(\mathrm{r}^{2}=0.75, \mathrm{n}=11\right.$ homesteads suffering at least one attack during the study, $\mathrm{p}=0.0006$, linear regression)

per month. The typical boma possessed a single wall around the homestead with an average height of 1 to $2 \mathrm{~m}$ and medium to high transparency, and an average of 3 dogs. Across all 43 homesteads, there was no significant correlation between the number of attacks and the number of walls, wall transparency, building material used to construct the walls, wall height, number of dogs, number of livestock, proximity to adjacent homesteads, proximity to water sources, or habitat. Restricting the analysis to the 15 bomas that suffered at least 1 attack at the kraals, the only factor that was consistently related to attack rate was the number of people living at the homestead $\left(\mathrm{r}_{\mathrm{s}}=-0.62\right.$, $\mathrm{n}=15, \mathrm{p}=0.015)$ : small homesteads appeared to be more vulnerable to depredation. However this result should be interpreted with caution since the appropriate level of significance for a test involving 11 independent variables requires a Bonferroni correction of $0.05 / 11=0.0045$.

\section{Lion killing by Maasai}

Maasai elders and NCA informants reported details on 81 organized lion hunts between 1965 and 2003. According to these reports, lion hunting by young Moranis is largely motivated by cultural beliefs and cattle depredation often merely provides an excuse to carry out ritual lion killings. Because many ritual lion hunts may have been deliberately misclassified by the elders as retaliatory killings against livestock predation, we have not attempted to separate the 2 contexts in our analysis.

In comparable studies in Laikipia (Ogada et al. 2003) and Tarangire (Kissui 2008), pastoralists killed lions in direct proportion to the number of livestock killed by lions (also see Holmern et al. 2007). In the NCA, a similar relationship was observed across 3 of 4 sub-regions in the study area: lions suffered the highest humaninflicted mortality in the woodlands, moderate mortality in Olduvai, and lowest mortality in the highlands, reflecting parallel differences in livestock predation across the same 3 areas (Fig. 4A). However, lion predation was relatively rare in the open plains of the NCA, yet the rate of lion killing was nearly as high as in the woodlands. While lion killing and livestock predation
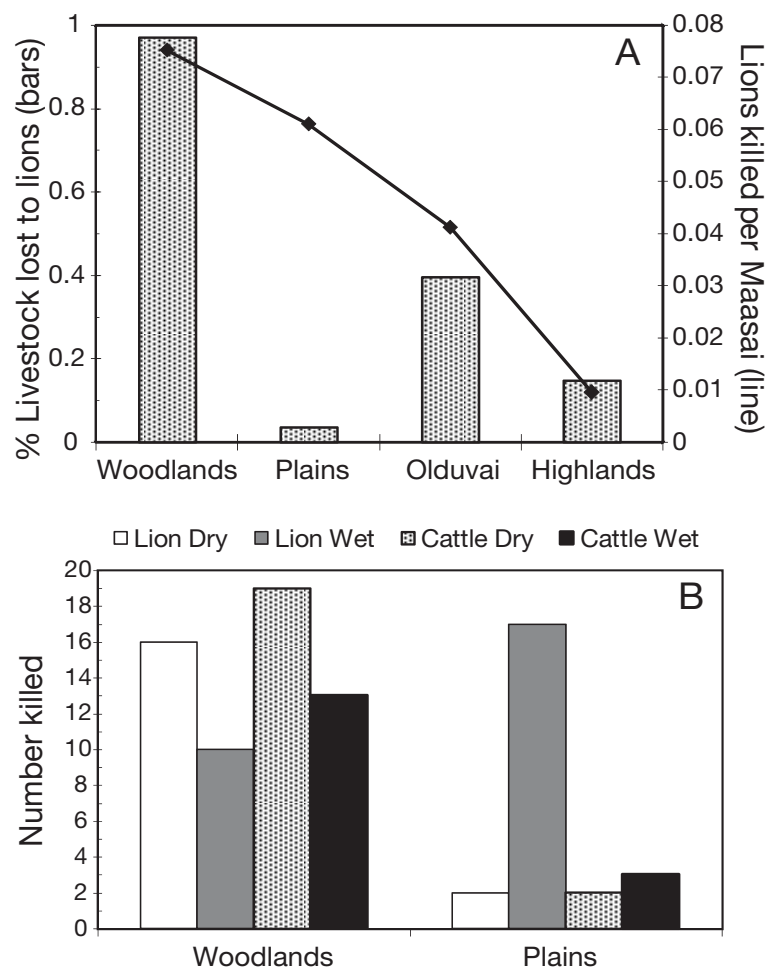

Fig. 4. Variation in livestock losses vs. lions killed by Maasai. (A) Percentage of livestock lost to lions (bars) vs. lions killed per Maasai (line) across 4 broad geographical areas in the NCA. (B) Number of livestock lost to lions (hatched: dry season; black: wet season) vs. number of lions killed (white: dry season; gray: wet season) in the 2 highest-conflict areas 


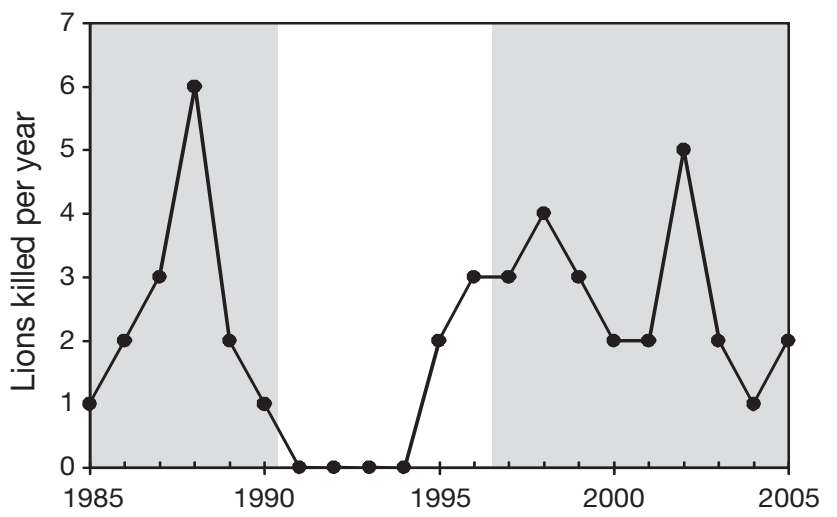

Fig. 5. Panthera leo. Number of lions killed by Maasai in the NCA each year from 1985 to 2005. Shaded areas indicate years when Moranis were active. The age set initiated in 1983 (named Il'kidortu) was elevated to young elder status (Ol Bayoni) in 1991; the 1997 age set (Il'koriyanga) had not been elevated to Ol Bayoni status by January 2007

were both highest in the dry season in the NCA woodlands, lion killing on the plains was far higher in the wet season despite a lack of seasonality in livestock predation (Fig. 4B).

The number of reported lion-killings was $2.01 \pm 1.67$ (SD) animals each year from 1985 to 2005. Lion-killings did not vary with the number of livestock lost each year, but clearly reflected the presence of recently initiated cohorts of Morani (Fig. 5).

\section{DISCUSSION}

Our analyses provide circumstantial evidence of 2 separate contexts for lion killing in the NCA. Figs. 4 \& 5 suggest that Maasai primarily kill lions in retaliation for livestock depredation throughout most parts of the pastoralist NCA, but the short grass plains serve as ritual hunting grounds where Maasai warriors regularly kill nomadic Serengeti lions during the wet season. Since Ala-mayo is illegal, Fig. 5 might be expected to underestimate the true off-take of lions in the NCA. However, the Maasai elders did not withhold any information on the date and location of any lion killings that we had confirmed independently and they even led us to the remains of lions that had recently been killed. We only had reason to suspect people's veracity over the context of each lion killing. In one case, we arrived to find a group of Maasai who had just speared a radio-collared Serengeti female and claimed that that they had killed her in response to a cattle depredation $30 \mathrm{~km}$ away on the previous day. The radiocollared lion could not have killed their livestock, nor was it likely that this particular group of Maasai had travelled $30 \mathrm{~km}$ overnight.
We discuss the 2 contexts of lion killing separately because of the strikingly different impacts on the respective lion populations.

\section{Ala-mayo}

The short-grass region in the NCA study area is known locally as Angata Kiti and we received several reports that Morani would travel to Angata Kiti from other parts of Maasai land during the rainy season specifically to participate in Ala-mayo. However, if the data in Fig. 5 are even roughly accurate, the impact of Ala-mayo on the Serengeti lion population is trivial. We estimate the total Serengeti population to comprise 3500 lions, long-term records from our Serengeti study show a consistent increase in lion numbers in the sector closest to the NCA over the past 40 yr (Packer et al. 2005) and the number of presumed Ala-mayo killings is lower than the trophy quotas in the neighboring trophy hunting concessions (which total 24 males per year). In addition, dozens of lions are inadvertently killed in poachers' snares each year throughout the Serengeti ecosystem (Tanzania National Parks unpubl. data). Finally, most of the nomadic lions that enter the NCA are dispersing subadults, aging males or females with dependent offspring that have temporarily departed from their Serengeti prides to avoid infanticide by incoming males (Packer \& Pusey 1983). Thus, many of these nomadic individuals would be expected to experience high mortality anyway.

\section{Retaliatory killings}

Across the rest of the NCA, retaliatory lion killing appeared to occur in direct proportion to the proportion of livestock lost to predation (Fig. 4). Lions clearly supplement their diet with livestock and Maasai livestock husbandry is largely organized around the threat of predation. We could not find any statistically significant effect of boma construction or composition on the risk of night-time attacks. But the extent of cattle losses to lions could be reduced considerably if the Maasai replaced children with Moranis as their primary herders and increased the number of herdsmen for each herd (Fig. 3).

The underlying problem in the NCA is the implausibility of a continuously growing human population coexisting with lions while surviving on an inflexible food supply (Fig. 6A); the resultant per capita drop in protein (Fig. 6B) renders any livestock losses intolerable to the pastoralist population. Outside the Crater floor, there are $\sim 27$ lions surviving in $\sim 4$ resident prides at Endulen, Olduvai and Ndutu. We cannot estimate 

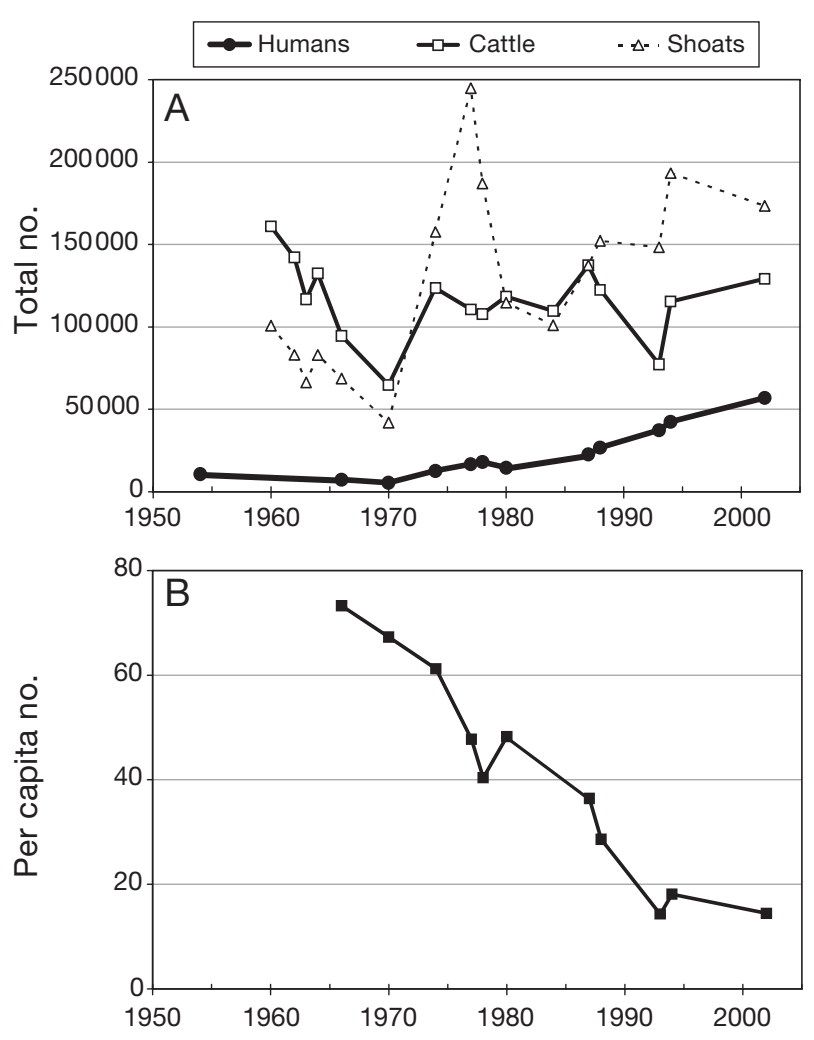

Fig. 6. Population trends in the NCA and livestock per capita. (A) Total number of Maasai, cattle and shoats in the NCA.

(B) Per capita number of 'shoat equivalents' in the NCA. Each cow is considered to be equal to 5 shoats

historical lion densities throughout the NCA, but some of the most hospitable lion habitats have only been occupied by Maasai settlements for the past 10 to $20 \mathrm{yr}$, so resident lions were probably more abundant in the past.

In the future, resident lions in the NCA may become entirely restricted to the Crater floor and Lake Ndutu. The Crater floor was declared off-limits to pastoralists because of human-wildlife conflicts in the 1970s. During our study period, an average of 57 lions resided on the floor of the Ngorongoro Crater (Kissui \& Packer 2004). The crater lions occasionally enter pastoralist areas in the NCA highlands but do not suffer appreciable anthropogenic mortality (B. M. Kissui, A. Mosser \& C. Packer unpubl. data). Lake Ndutu is immediately adjacent to the Serengeti National Park and holds the only other permanent tourist camp. While Ndutu lions frequently interact with lions from the Serengeti, the crater lions have become so completely isolated by human settlements that the population is highly susceptible to infectious disease, perhaps owing to a history of close inbreeding (Kissui \& Packer 2004). Translocations may therefore become necessary to reinvigorate the crater population (see Trinkel et al.
2008) unless land-use in the NCA is dramatically reorganized.

The local Maasai asked the Tanzanian government to relax the ban on cultivation inside the NCA in 1992 (Thompson 1997, McCabe 2003) - the same year that per capita livestock levels reached their current low level-but the resultant increase in agriculture directly contravened the principles of sustainable coexistence that allowed the Maasai to remain inside the NCA in the first place. New legislation took effect in January 2007 that expressly forbade all forms of agriculture in the NCA and the Maasai also face increasing governmental pressure to emigrate from the area. Conflicts between lions and Maasai exemplify some of the larger issues in this dispute. Retaliatory killing is legal, but any sort of predator control raises serious long-term conservation challenges. Improved livestock husbandry might ameliorate the problem, but the consequences of continued human population growth in the NCA will likely overwhelm even the most effective mitigation strategies.

Acknowledgements. We thank B. Kissui and the anonymous referees for comments, R. Boone and A. Mosser for assistance with Figs. $1 \& 2$, and the Tanzania Wildlife Research Institute and Ngorongoro Conservation Area Authority for permission to conduct research. This material is based upon work supported by the National Science Foundation under Grant No. 0343960 .

\section{LITERATURE CITED}

Borrini-Feyerabend G, Buchan D 1997. Beyond fences: Seeking social sustainability in conservation, Vol 1. A process companion. IUCN, Gland

Coast E (2002) Maasai socio-economic conditions: Crossborder comparison. Human Ecol 30:79-105

Farr TG, Rosen PA, Caro E, Crippen R and others (2007) The Shuttle Radar Topography Mission. Rev Geophys 45:RG2004, doi:10.1029/2005RG000183

Fosbrooke H (1972) Ngorongoro: The eighth wonder. Andre Deutsch, London

> Holmern T, Nyahongo J, Røskaft E (2007) Livestock loss caused by predators outside the Serengeti National Park, Tanzania. Biol Conserv 135:518-526

Homewood KM, Rodgers WA ( 1987) Pastoralism, conservation and the overgrazing controversy. In: Anderson D, Grove R (eds) Conservation in Africa: people, policies and practice. Cambridge University Press, Cambridge, p 111-128

Homewood KM, Rodgers WA (1991) Maasailand ecology: Pastoralist development and wildlife conservation in Ngorongoro, Tanzania. Cambridge University Press, Cambridge

Kissui BM (2008) Livestock predation by lions, leopards, spotted hyenas, and their vulnerability to retaliatory killing in the Massai steppe, Tanzania. Anim Conserv 11:422-432

Kissui BM, Packer C (2004) Top-down regulation of a top predator: lions in the Ngorongoro Crater. Proc R Soc Lond B Biol Sci 271:1867-1874

Kolowski JM, Holekamp KE (2006) Spatial, temporal, and physical characteristics of livestock depredations by large carnivores along a Kenyan reserve border. Biol Conserv 128:529-541 
McCabe JT (2003) Sustainability and livelihood diversification among the Maasai of Northern Tanzania. Human Organ 62:100-111

> Ogada M, Woodroffe R, Oguge N, Frank L (2003) Limiting depredation by African carnivores: the role of livestock husbandry. Conserv Biol 17:1521-1530

Packer C, Pusey AE (1983) Adaptations of female lions to infanticide by incoming males. Am Nat 121:716-728

Packer C, Hilborn R, Mosser A, Kissui B and others (2005) Ecological change, group territoriality and non-linear population dynamics in Serengeti lions. Science 307: 390-393

Editorial responsibility: Anna Nekaris,

Oxford, UK
Sinclair ARE, Norton-Griffiths M (1979) Serengeti: dynamics of an ecosystem. University of Chicago Press, Chicago, IL Spear T, Waller R 1993. Being Maasai: Ethnicity and identity in East Africa. James Curry, London

Spencer P (1988) The Maasai of Matapato: a study of rituals of rebellion. Indiana University Press, Bloomington, IN

Thompson DM 1997. Multiple land use: The experience of the Ngorongoro Conservation Area. IUCN, Gland

Trinkel M, Ferguson N, Reid A, Reid C and others (2008) Translocating lions into an inbred lion population in the Hluhluwe-iMfolozi Park, South Africa. Anim Conserv 11:422-432

Submitted: August 17, 2007; Accepted: July 21, 2008

Proofs received from author(s): October 10, 2008 